\title{
ARTIG0S
}

\section{AS ORIGENS DO LATIFÚNDIO: DA "VILLA" ROMANA AOS ENGENHOS E FAZENDAS DO BRASIL COLONIAL $\left(^{\star}\right)$.}

Latifundia, perdidere Italiam (Plfnio-o-Antigo).

E. SIMÕES DE PAULA

Professor de História da Civilizaçāo Antiga e Medieval da Faculdade de Fllosofia, Letras e Ciencias Humanas da Universidade de Sáo Paulo.

\section{INTRODUÇÃO GERAL.}

Professôres francesies de História que lecionaram na Faculdade de Filosofia, Ciências e Letras da Universidade de São Paulo, principalmente aquêles a quem a História Antiga e a da Idade Média eram familiares - como Émile Coornaert, Fernand Paul Braudel, Jean Gagé, Maurice Lombard, Michel Mollat - ficaram impressionados ao encontrar entre nós certos traços - principalmente através da obra hoje clássica de Gilberto Freyre (1) - da civilização que imperou na Europa Ocidental até os fins da Idade Média, principalmente no que se refere ao regime de trabalho, técnicas agrícolas e economia. Refletindo nêsse fato, nos abalançamos a apresentar aos colegas êste pequeno ensaio, mais com o fito de, juntamente com êles, fazermos um pouco de história comparada, do que apresentar êste trabalho como uma pesquisa inteiramente original.

\section{I. - A "VILLA" ROMANA.}

\section{1. - Introdução.}

Com a conquista dos territórios circunvizinhos, o velho quadro agrário de Roma foi desaparecendo pouco a pouco. A figura lendária de Cincinato, senador da República, lavrando pessoalmente sua terra e atendendo uma delegação de colegas quando empunhava a rabiça do seu arado, também foi se esfumando no passado e deixou

(*). - Trahalho anresentado ao $\pi$ T Simnósio Naclonal dos Professôres Unlversitários de História. (Nota da Redaçäo).

(1). - Gllberto Freyre, Casa Grande \& Senzala. A formação da família brasiletra sob o regime de economia patriarcal. Mala \& Schmidt Ltda. Rlo de Janeiro. 1933. XLVI + 519 pp. 
de ser regra geral. A pequena propriedade, transforma-se cada vez mais em exceção e o latifúndio, pelo contrário, vai se tornar comum. A velha clientela, baseada na proteção do pequeno lavrador pelo seu patrono, paulatinamente foi sendo substituida por uma clientela eleitoral em Roma, que forçava a eleição nos comícios e garantia o sucesso político de quem lhe propiciava o sustento.

A conquista, com o confisco de grandes porções das melhores terras dos vencidos, modificou completamente a agricultura italiana. Antes, quando a pequena propriedade era a regra, o lavrador tinha um mercado garantido para a sua produção; agora, com o aviltamento dos preços dos produtos agrícolas - principalmente do trigo consequiência dum verdadeiro dumping, oriundo dos tributos dos países subjugados pagos in natura. Até a própria paisagem agrícola modificou-se: certas culturas são abandonadas e dão lugar a outras.

Quando a guerra era no Lácio, ou mesmo na Itália, o cidadão-soldado - pois só os proprietários podiam ser legionários - após algumas semanas de ausência conseguia ainda, com esfôrço, recuperar o tempo perdido e obter uma colheita razoável. Mas quando as guerras se travaram na África, na Ásia Menor, mesmo na Gália ou na Espanha, o cidadão-camponês não podia acudir mais a tempo a sua propriedade e era obrigado, na sua volta, a endividar-se ou vendê-la, por não haver conseguido saldar os seus compromissos. Acabava, quase sempre, por emigrar para Roma, onde.o seu voto tinha valor e assim aumentava a sempre tumultuada plebe que exigia, para acalmar-se, panen et circenses. Assim, a própria conquista condicionou a formação do latifúndio, cujos proprietários não se entregavam mais ao plantio do trigo por considerá-lo anti-econômico, e, para substituí-10 , por tôda a parte plantaram oliveiras, vinhas e pastagens, que ocupavam menos mão-de-obra, favorecendo assim um êxodo rural rumo às grandes cidades, principalmente para Roma, onde o voto do cidadão tinha uma grande importância, pois que êle já pertencia a uma das tribos rurais que dominavam o cenário político dos comícios. Paulatinamente o cidadão-soldado-camponês foi sendo substituído pelo escravo. Tão grande foram alguns dêsses latifúndios que no início do Império um famoso argentário. Trimalcião, gabava-se de que podia ir de Roma a Nápoles sem sair de suas terras.

\section{2. - O problema do "ager publicus".}

A formação do ager publicus foi consequiência direta da conquista, pois na Antigüidade o vencido sempre pagava com o confisco de suas terras a derrota sofrida. Assim, Roma seqüestrava em seu proveito as terras subjugadas conforme a resistência oferecida, tendo existido mesmo casos em que as deixou quase inteiramente nas mãos dos seus antigos proprietários, quando, por exemplo, tivesse havido uma pré- 
via deditio. Os casos mais comuns eram aquêles do confisco da metade ou do terço das terras dos vencidos, devendo êstes ainda pagar um tributo (stipendium ou vectigal).

As terras confiscadas constituiam o ager publicus, isto é, era território pertencente ao Estado. Teòricamente isso devia enriquecer sobremaneira o povo romano, mas na realidade não era o que acontecia, pois a nobilitas (aristocracia senatorial) se apossava dêsse ager publicus, com a conivência dos magistrados, que pertenciam à sua própria classe social, para aumentar as suas já vastas propriedades sob a forma da occupatio, deixando aos ex-soldados os piores pedaços, principalmente os terrenos incultos que exigiam um grande trabalho para pô-los em condições de produzir. E' verdade que o Estado arrendava êsse ager publicus, mas sòmente os ricos ou as companhias de publicanos (societates publicanorum) podiam pagar imediatamente o exigido pelo erário nos leilões que procediam das terras ocupadas, sem falar do pronto emprêgo da mão-de-obra servil para poder usufruir imediatamente a propriedade adquirida.

Os loteamentos gratuitos deveriam ter sido feitos a miude, mas a medida que a nobilitas foi-se assenhoreando das terras, principalmente depois das Guerras Púnicas, ela foi se recusando gradativamente a repartir os territórios do Estado, julgando-se a única usufrutuária das terras conquistadas com o sangue e o suor de todos os legionários e dos socii (aliados) que mais tarde também se rebelaram, dado o tratamento desigual que receberam. E'verdade que foram fundadas diversas colônias, algumas romanas e outras de direito latino, destinadas aos soldados que terminavam o seu tempo de serviço militar, por haverem tomado parte em determinado número de campanhas. Essas fundações foram ficando cada vez mais raras e cada vez mais longe da Itália .

Essa situação explica o que aconteceu com os Gracos que, apreensivos com a diminuição constante dos efetivos das legiões, solicitavam uma reforma agrária que possibilitasse a distribuição do ager publicus entre os cidadãos pobres, para que o exército pudesse recrutar mais soldados. Não vamos entrar na problemática dessa crise, mas queremos dizer que a oligarquia senatorial, completamente cega, não percebeu o êrro em que incorria e, mantendo sua política egoista, permitiu a eclosão duma grande crise que culminou com a ascenção ao poder de diversos condottieri: Mário, Sila, Pompeu, César, até que, finalmente, após tremenda guerra civil, Otávio conseguiu derrotar Marco Antônio e tornar-se senhor único da situação em Roma.

Enquanto isso se passava, a situação das propriedades evoluia no mesmo sentido anterior, isto é, da concentração de terras nas mãos da nobilitas, com o consequiente desaparecimento da primitiva noção do ager publicus. Roma, com suas guerras contínuas, esgotara a capacidade dos seus cidadãos-soldados e fomentara a concentração 
dos clientes, agora verdadeiramente dependentes dos seus patronos e vivendo da sportula distribuída quase que diàriamente nas portas das casas da nobilitas. Cada vez mais a plebe se impunha e o perigo da sua revolta fazia com que os candidatos a postos políticos oferecessem festas magníficas para que seus nomes fôssem lembrados e sufragados nas urnas.

A situação agrária da Itália - e por extensão em diversas províncias romanas - modificou-se bastante com êsses acontecimentos. O Senado, inadvertidamente, deu a Mário o direito de alistar nas legiões os proletários (proletarii - os que só tinham a prole como riqueza) e com isso abriu a série de quarteladas que terminou com a República, pois êsse soldados não eram mais camponeses e por isso se mostravam decididamente favoráveis a seus generais e não à causa senatorial. Aliás, isso teria de acontecer mais cêdo ou mais tarde, pois a constituição romana vigente fôra feita para uma cidade e não para o Império que ia lentamente se formando. Como dissemos mais acima, a paisagem agrária modificara-se bastante com o dumping do trigo e a plantação sistemática de oliveiras, vinhas e pastagens. Os latifúndios aumentavam, assim como a plebe, sempre manejável por políticos inescrupulosos que acenavam com uma reforma agrária, mas que estavam apenas interessados na posse do poder. Esses políticos sentiam pelo menos o problema, pois durante os triunviratos diversas propriedades foram confiscadas e distribuidas em lotes entre os soldados veteranos, mas sempre eram imóveis de senadores e apaniguados que haviam sido vencidos. Exemplo típico dêsse confisco, temos no caso do poeta Virgílio que teve sua propriedade distribuida aos veteranos de Otávio. A estabilidade ocorreu cóm Augusto e as províncias e a Itália se beneficiaram extraordinàriamente com a pax romana, uma das chaves do seu sucesso.

\section{3. - O Alto-Império.}

O povo romano, composto principalmente de camponeses, sempre se preocupava, como é óbvio, com os problemas agrícolas. Durante a República, na Itália, apesar da crescente decadência, a agricultura tinha ainda um lugar proeminente nas atividades usuais da população. Con o Império, houve uma grande mudança, perfeitamente visível na política de conquistas e incorporações de novas províncias. O latifúndio torrou-se a regra nesses territórios que, sob a direção técnica dos italianos, foram explorados metódica e intensamente, beneficiando-se todos com as benesses da pax romana. Assim foram exploradas a Sicília, a Sardenha, a Espanha, a Gália, a Ásia. O Egito e a África do Norte, entretanto, são as duas regiões onde essa política foi mais marcante, pois foi aí que se criaram inúmeros domínios imperiais e por isso mesmo essas províncias foram muito beneficiadas com aquedutos, 
barragens, cisternas, poços, etc.. Graças a essa aparelhagem, essas duas regiões tornaram-se o "celeiro de Roma", principalmente no que tange à cultura do trigo. A Itália, a Sicília, a Narbonense, a Åfrica do Norte, as ilhas do Egeu cultivavam também a vinha; a Africa do Norte e a Itália plantavam inúmeros olivais. O pastoreio prosperou na Ásia Menor e o papiro foi cultivado em larga escala no Egito.

$\mathrm{O}$ intenso comércio marítimo e aquêle que era feito pelas vias romanas, difundiu a civilização romana, principalmente pela bacia do Mediterrâneo, conseguindo especializar a economia de diversas regiões, mas a Itália foi perdendo terreno paulatinamente em benefício das províncias.

A Affrica do Norte pode servir de exemplo do que aconteceu nas demais províncias, pois transformou-se numa colônia de exploração, onde existiam, inicialmente, poucos italianos e êsses mesmos eram funcionários, militares ou descendentes de veteranos, havendo entre êles sòmente alguns proprietários. $\mathrm{O}$ grosso da população era ainda composto dos indígenas que trabalhavam e arroteávam as terras (2). De fato, a Berbéria merecia o título de "celeiro de Roma", pois as suas plantações de trigo foram aumentadas, assim como o plantio 'de oliveiras e da vinha, produtos que aliás já eram cultivados no período púnico. As culturas foram favorecidas pelos imperadores que mantiveram a ordem e assim o Magrebe tomou o aspecto dum imenso domínio sistemàticamente explorado, para que a plebe romana pudesse receber o seu alimento e não se rebelasse. Com a pax romana, a população aumentou e para mantê-la e para satisfazer os especuladores, foi necessário aumentar a área ocupada, desalojando conseqüentemente, muitas tribos nômades.

Augusto deu um vigoroso impulso à colonização, ao mesmo tempo que criava colônias militares para manter os' nômades vigiados, organizando para êsse fim a famosa III Legião Augusta. Esse imperador distribuiu numerosos lotes a colonos e procurou fixar neles emigrantes italianos arruinados pela crise agrícola romana, ao mesmo tempo que, para favorecer aos capitalistas que punham seu dinheiro no fomento do trigo, empreendia novas conquistas para aumento da área ocupada. A consequiência dessa política foi o desapossamento das terras dos indígenas. Foi tal a ganância que se tornou necessário anexar a Numídia e depois a Mauritânia. Plínio, comentando êsse fato, dizia que seis proprietários apenas dividiam entre si todo o solo da província África (3).

Na África, como na Arábia, na Síria e em geral em tôdas as províncias, Roma dividira a terra em duas parcelas: a pior para os antigos proprietários, os quais na sua maioria passaram a lavrar as

\footnotetext{
(2). - Ch. - André Julien, Histoire de l'Afrique du Nord. Parls. Payot. Prefáclo de Btephane Gsell. 357 figs. 2 mapas. pp. 122-123.

(3). - Apud Julien, op. cit., pág. 170
} 
suas próprias terras como trabalhadores agrícolas, e a outra, repartida em imensos domínios e exploradas de longe pelos membros da família imperial e da aristocracia senatorial, ou então dividida em pequenas parcelas e distribuida aos veteranos e à aristocracia bérbere. A consequêencia lógica dessa política de desapossamento foi o alargamento do limes e a expulsão dos nômades para os oásis do Saara. Com essa migração dos nômades, os negros que habitavam êsses pontos dágua rumaram para o Sul, em direção às florestas e fundaram aí no Niger diversos reinos, sendo o mais importante o de Ghana. Esse grande deslocamento de populações só foi possível no deserto com a introdução do camelo em grande escala, principalmente a partir da época de Septímio Severo.

Com os Severos já se inicia o Baixo Império e começa a decadência romana, com as constantes revoltas dos indígenas e a conseqüente expulsão dos colonos. A solução para enfrentar tal problema foi a fortificação das propriedades', cujas casas principais adquiriram o aspecto duma verdadeira fortaleza.

\section{4. - $O$ regime de terras.}

As terras confiscadas aos senadores que tomaram partido pelos triúnviros vencidos, ou aquelas que tinham sido tomadas aos indígenas, constituiam os imensos domínios imperiais (saltus). Os senadores, apesar dos confiscos de Nero, possuiam ainda imensas propriedades (saltus privati), assim como cidades, tribos e até companhias de publicanos. A regra geral foi o latifúndio.

Geralmente o imperador e os seus familiares não exploravam diretamente os seus domínios, pois costumavam arrendá-los a particulares ou a companhias de publicanos que exploravam os pequenos cultivadores (coloni). Êsses colonos eram muitas vêzes os antigos ocupantes do solo por hereditariedade e geralmente indígenas agrupados em aldeias (vici), dentro da grande propriedade, ou junto dos edifícios principais. Formavam associações autônomas de caráter religioso, pois elegiam os seus presidentes (magistri) e organizavam as feiras regionais onde quase só compareciam os' camponeses (mundinae). Muitos dêsses vici adquiriram personalidade jurídica, transformando-se em cidades.

Os colonos não pagavam suas contribuições ao fisco imperial, mas sim aos concessionários (conductores) que haviam arrendado as propriedades por cinco anos, com o direito de cultivar em seu proveito as terras não loteadas e de receber as quota-partes das colheitas provenientes das parcelas loteadas. Funcionários imperiais (procuratores Augusti) deviam proteger os colonos e ajudar os conductores a receber as suas rendas (4). Esses conductores eram pessoas muito in(4). - Ibidem, pág. 182. 
fluentes - em geral grandes capitalistas - e por isso costumavam subornar ou intimidar os procuradores imperiais.

Mais abaixo na escala social estavam os procuradores do saltus, simples libertos e meros agentes executores de ordens que, entretanto, obrigavam os colonos a obedecê-los com o chicote, com varas ou sob ameaças de prisão. No escalão superior o procurador da regio, muitas vêzes personagem da ordem eqüiestre, tinha a missão platônica de manter a liberdade das ofertas em leilão, em face dos conductores agrupados e solidários, e fixar as regras da administração fiscal; no cimo da administração havia o procurador do tractus que residia em Cartago, cavaleiro com alta paga e representando o imperador, ao qual obedecia; dirigia ou contro'ava os procuradores e dispunha para isso da fôrça armada.

Muitas vêzes os desmandos do procurator do saltus, ou então as revoltas dos colonos contra a exploração dos conductores, terminavam em sangrentas repressões, com o exército a debelar os levantes. A administração romana nada recusava às poderosas companhias de publicanos. Certos domínios privados (saltus privati) tinham uma organização análoga ao saltus imperiais, outras eram alugados a arrendatários ou dirigidos por um intendente (villicus) (5).

A vida quotidiana duma grande propriedade, nesse periodo, pode muito bem ser acompanhada através duma grande série de mosaicos conservados na Africa do Norte e que vão desde o II século até a época bizantina. Podemos ver nessas peças os edifícios centrais duma grande propriedade, jardins, estábulos, oliveiras, vinhas, cavalos, pastores vigiando rebanhos, mulheres fiando na roca, armazens cheios de víveres etc. Dá uma perfeita visão de como seria a vida no campo.

Outros mosaicos mostram uma villa fortificada com torreões e muralhas - como a propriedade campestre do Senhor Júlio, descoberta em Cartago em 1920 (6) — sem dúvida preparada para resistir aos ataques dos nômades, com o senhor vigiando os trabalhos agricolas (oliveiras, cereais, vinha, criação de gado). Sua mulher, coberta de jóias, está sentada à sombra duma árvore, tendo junto de si uma cesta com frutas e fiscalizando o trabalho das servas. São os dois personagens típicos farmers da época. Esses mosaicos nos mostram, pois, o duro labor agrícola e por êles podemos ver também os pequenos proprietários, os colonos e os servos trabaihando num grande dominio. Alguns landlords habitavam essas propriedades, mas a maioria, inclusive o Imperador e sua família, residiam em Roma. Os seus' intendentes (villici) é quem superentendia os serviços. Os pequenos proprietários procuravam se manter, mas geralmente eram compelidos a entregar suas terras por dívidas. Assim, pouco a pouco, formou-se na

r(5). - Ibidem, pág. 182.

(6). - Ibidem, pág. 183-184. 
Africa do Norte, como nas outras províncias, uma grande massa de escravos, de trabalhadores agrícolas e de colonos de parceria, que entregavam sua renda aos conductores das sociedades publicanas ou aos procuradores imperiais.

\section{5. - A mão-de-obra no Baixo Império.}

No tempo de Catão e de Varrão, as grandes propriedades eram cultivadas por equipes de escravos: o trabalho escravo substituira por tôda a parte o trabalho livro. Até mesmo os guardiões dos rebanhos (pastores) são escravos, assim como o actor que administrava a grande propriedade. Mas o modo de utilização da mão-de-obra servil mudou com o Baixo-Império, pois parece que os servos rurais não trabalham mais em equipes e sim recebiam lotes de terras e se comportavam como verdadeiros arrendatários. A mão-de-obra escrava deixou de ser preponderante nas grandes propriedades, porque evidencia-se no IV século o seu declínio (7).

Desde a época de Nero os imperadores instalaram bárbaros, prisioneiros de guerra, como cultivadores. Não eram pròpriamente escravos, ou no máximo poderiam ser considerados como escravos do Estado. Esses homens foram repartidos entre os grandes proprietários que os colocaram à frente dum lote de terra. Assim nasceram os casarii (8) que deviam pagar o impôsto de capitação que o seu senhor aparentemente devia entregar ao Estado. Quando êsse impôsto foi abolido, êsses tributarii se consideraram livres .

O colonus foi no Alto-Império um arrendatário livre e os proprietários tinham grande trabalho para retê-lo no seu lote; mas já no Baixo-Império a situação é bem outra, pois perdera o direito de abandonar a propriedade e transformara-se em quase-servo. A condição de colono no Baixo-Império é, pois, a de um homem que não pode sair de sua tenure (9); não lhe permitiam possuir uma propriedade imóvel a título pessoal; não consentiam que fôsse separado da terra em que trabalhava, nem pela sua vontade própria, nem pela do seu senhor; sua condição social foi hereditária e por isso não podia casar-se fora da sua classe e se a propriedade em que vivia fôsse desmembrada a sua família também poderia ser dividida. O colonato foi se estendendo paulatinamente a todo o Império e a sua situação se foi agravando com a perda progressiva dos seus privilégios. A conquista romana, que libertara os escravos, agora no Baixo-Império instituiu o

(7). - André Plganiol, L'Empire chrétien (325-395). Tomo IV da "Fistolre Romaine" ds Coleçso "Histoire Générale" dirigida por Gustave Glotz. Paris. Presses Universitaires de France. 1947., pág. 276.

(8). - Servus qui quasi colonus in agro erat (Ulp., Dig., XXXIII, 7, 12 \&).

(9) . - Náo encontramos uma traduçáo satisfatória para esse têrmo que é essencialmente medieval e que talvez pudesse ser compreendido como uma "parcels" do feuco. 
regime de semi-servidão. Isso só se pode explicar pelas dificuldades que encontravam os proprietários em reter os seus trabalhadores agrícolas e só o conseguiam com o auxílio do Estado.

As grandes propriedades imperiais foram organizadas mais ou menos nas mesmas bases dos grandes domínios helenísticos, onde a servidão da gleba era quase a regra. O direito helenístico no IV , século teve uma grande influência no direito romano. Mas segundo Piganiol (10), foi o regime fiscal o responsável pela servidão da gleba, pois as principais rendas do Estado eram oriundas de duas fontes: os impostos sôbre as terras cultivadas e o da capitação, cobrado aos camponeses. As terras abandonadas aumentaram de área, os arrendatários tornaram-se raros e os camponeses procuravam emigrar para regiões onde a sua sorte pudesse ser melhorada. Como consequiência disso as colheitas ficavam perdidas e o fisco sem impostos. O Estado, interessado em assegurar as suas rendas, garantiu aos proprietários a estabilidade dos trabalhadores agrícolas: daí o regime da servidão da gleba (coloni originales). Examinando de perto essa situação, chegamos à conclusão que a origem dêsse fato deve ser procurada na famosa crise do III século, que abalou profundamente o Império Romano em todos os seus setores.

Havia ainda no pessoal que habitava uma grande propriedade uma figura interessante: o inquilinus que não estava ligado à gleba e tinha o direito de sair quando lhe aprouvesse. Esses trabalhadores errantes desgostavam os procuradores pelo exemplo que davam aos servos, daí o empenho que punham em assimilá-los aos demais, os coloni originales, e acabaram finalmente por conseguí-lo.

\section{6. - A propriedade imobiliária no Baixo-Império: a "villa".}

Foi o declínio da escravidão que determinou o aspecto mais característico da grande propriedade no Baixo-Império: a sua divisāo em duas partes distintas, uma explorada pelo senhor, ou melhor pelas corvéias que exigia dos seus homens e a outra, composta de pequenas parcelas cultivadas pelos escravos casarii, pelos tributarii e mais geralmente pelos coloni originales. Pequenas explorações agrícolas inclusas na grande propriedade serão transformadas em mansi na Idade Média.

Ausônio (11) nos dá a dimensão duma propriedade que êle chama de média: 50 hectares de terras arroteáveis, 25 de videiras, 12 de pastos, 175 de bosques, com um total de cêrca de 260 hectares. Os ricos possuiam grupos de grandes domínios (massae fundorum) e numa dessas propriedades às vêzes habitava tôda uma aldeia.

(10). - Płgantol, op. cit. pég. 277

(11). - Apud Piganiol, op. cit., pág. 278. 
Paládio (12) diz no seu manual agrícola, datado do fim do IV século, que era necessário cada domínio possuir operários de tôdas as especialidades, como: carpinteiros, tanoeiros, ferreiros, oleiros, etc., a fim de não dar aos camponeses o pretexto de fugirem para a cidade. Assim, com êsise testemunho, já podemos dizer que a economia começa adquirir o aspecto dum organismo fechado sôbre si mesmo, autárquico.

O aumento dos impostos obrigou os proprietários a melhorarem as técnicas de exploração agrícola. Pensamos mesmo que o declínio da escravidão se deve em parte ao desenvolvimento de novas máquinas, como o moinho dágua, arados aperfeiçoados, etc.

Neste período não mais existe o ager publicus, pois todos os bens do Estado se integraram no patrimônio imperial desde o reinado de Vespasiano. Mas no início do IV século cada cidade possuia ainda um patrimônio agrícola. Não sabemos em que época essas propriedades foram absorvidas pelo patrimônio imperial, talvez o fôssem desde a época do imperador Constâncio, pois Juliano-o-Apostata (13) a restabeleceu momentâneamente. Os bens dos templos não podiam separar-se daqueles das cidades e, como êstes, acabaram por serem incluídos nos bens da corôa. Fazemos uma distinção entre os bens pròpriamente imperiais (patrimonium) e aquêles que pertenciam pessoalmente ao principe (res privata) .

Já verificamos o regime de terras no Alto-Império. No período que estamos tratando - Baixo-Império - ainda existe muita cousa dessa antiga organização, mas os conductores a curto prazo ( 5 anos) foram substituidos por arrendatários a longo prazo, que acabaram por concluir um contrato de enfiteuse (14) (emphyteuticarii), ou tornaram-se mesmo possuidores a título perpétuo (perpetuarii) comprando êsse direito (jus perpetuum salvo canone), mas tinham que pagar os novos impostos e uma renda (canon) percebida pelo Estado e ainda por cima em moedas de ouro (15).

O problema das terras abandonadas começou a se agravar desde o fim do século II. O Estado procurou resolver o assunto isentando-as do pagamento dos impostos. No seu afã de recuperá-las, chegou a impor a quem comprasse um lote de terra boa a aquisição dura pedaço do terreno abandonado. Constantino obrigou mesmo os proprietários vizinhos a lavrar as terras abandonadas, ou pelo menos cuidar delas .

(12). - Ibidem, pág. 280.

(13). - Piganiol, op. cit., pág. 281.

(14). - Contrato pelo qual um proprietário transfere o seu domínio útil para outra pessoa, obrigando-se esta a pagar-lhe uma quantia determinada a que se đá o nome de fôro ou cánon.

(15). - Plganiol, op. cit., pág. 282. 


\section{II. - A IDADE MEDIA.}

\section{1. - Introdução.}

Com a barbarização da Europa Ocidental as cidades cairam em ruínas, sobrevivendo pràticamente aquelas em que o bispo pôde se manter e assim mesmo o número dos seus habitantes reduziu-se bastante em comparação com o período do Alto-Império. Devido à desordem então reinante, a Igreja tornou-se a verdadeira herdeira de Roma, pois todo o sistema administrativo e mesmo a hierarquia funcional - em grande parte - passou para a organização eclesiástica. Até o direito canônico abeberou-se no velho direito romano e o substituiu, até que êste, com o aparecimento das Universidades, foi novamente ensinado.

O comércio, intenso no Alto-Império, decresceu a partir da dinastia dos Severos, dando origem ao absolutismo do Baixo-Império e isto explica muito bem o que já dissemos sôbre a transformação dos latifúndios nas villae, grandes propriedades com uma economia restrita, voltada para si mesma, produzindo tudo e apenas na quantidade que necessitasse para o seu consumo.

\section{2. - A organização da grande propriedade $e$ a servidão.}

A burguesia teve uma grande influência durante tôda a Idade Média e isso causa admiração, pois os seus membros eram em núlmero bem pequeno em face da grande maioria rural. Onde houve concentração urbana foi no Império Bizantino e não no Ocidente, em que o quadro é completamente diferente. Em regra geral a sociedade medieval era essencialmente agrícola. A grande propriedade era a regra e atingiu o seu apogeu nos séculos XII e XIII, chegando pois até a época do renascimento urbano, cultural e sobretudo comercial, iniciando-se então a Baixa-Idade Média que já tem alguns aspectos semelhantes à Idade Moderna. Com isso não queremos dizer que não houvesse pequenas propriedades. Havia, mas em pequeno número e em determinadas regiões.

A grande propriedade medieval tinha em média 300 mansi, ou seja cêrca de 4.000 hectares, sendo que algumas possuiam mesmo muito mais (16). Geralmente as villae dum mesmo proprietário estavam afastadas, principalmente das aldeias e mosteiros. Havia ca. sos mesmo duma aldeia pertencer a dois ou três senhores. A situa-

\footnotetext{
(16) :- - A abadia de Saint-Germain-des-Près possula no inf́clo do IX século 33.000 hectares. Vide Ferdinand Lot, Christian Pfister e Francols L. Gansnot, Les destineés de l'Empire en Occident de 395 a 888. Tomo I da "Histoire du Moyen Age" da "Histoire Générale" dirigida por Gustave Glotz. Paris. Presses Unlversitaires de France. 1928, pág. 593.
} 
ção complicava-se quando a propriedade se estendia por regiões submetidas a diferentes senhores feudais, ou então por regiões de línguas ou dialetos também diferentes. Isso era muito comum no caso das terras da Igreja, pois elas se agrupavam ao sabor das doações que recebia. A conclusão a que chegamos é de que a grande propriedade se formava ao acaso.

Apesar de dispersa, a grande propriedade possuia uma organização centralizada. O centro era onde estava a residência habitual do proprietário: igreja, catedral, abadia ou castelo. Era dêsse centro que dependiam as diversas partes que continham uma ou mais aldeias. Cada uma dessas circunscrições dependia duma curtis (cour nas regiões de língua românica, hof na de língua germânica, manor na Inglaterra) onde se agrupavam os edifícios principais, estábulos, cavalariças, etc. Aí habitavam também os servi quotidiani, dagescalci, empregados nesses serviços, assim como o agente encarregado da administração: o villicus ou major (maire, mayer na Gália e na Germânia; seneschal, stewart ou baillif na Inglaterra). Esse villicus era escolhido entre os ministeriales, isto é, entre os servos de confiança que habitavam na casa do senhor; no comêço êle era demissível, mas com o tempo o cargo tornou-se hereditário, aliás de acôrdo com o mesmo processo dos senhores que se apossaram do feudo (17).

$\mathrm{O}$ conjunto das grandes propriedades dividia-se em três partes: a reserva senhorial (terra indominicata, terra salica), as ternures (terra beneficiata ou mansionaria) e a parte comum. A reserva senhorial era para o uso exclusivo do senhor, sendo trabalhada sob o sistema de corvéia (servitium, manuopera, carroperae, cuvada). A proporção das três parcelas variava de região para região, sendo costume colocar-se a reserva senhorial misturada entre os mansi. As parcelas arrendadas (mansus em latim, hufe em alemão e virgate ou yarland em inglês) eram do tamanho necessário que bastassem ao sustento duma família e propiciasse o pagamento da renda. A qualidade da terra influia também no tamanho do mansus. Os arrendamentos dessas parcelas estavam agravadas com corvéias e o pagamento de taxas era quase sempre feito in natura ao senhor. As terras de uso comum eram constituídas de bosques, pastagens, etc., de que todos tinham o direito de se servir (18).

Com exceção do senhor e da sua família, todos os habitantes da villa eram servos ou semi-servos. A escravidão antiga tinha desaparecido, principalmente devido à obra da Igreja, mas alguma cousa ficara da Antigüidade, como os servi quotidiani, os mancipia,

(17). - Henri Pirenne, Gustave Cohen, Henrl Focllon, La civilisation occtdentale au Moyen Age, du XIe au milieu du XVe siècle. Tomo VIII, da "HIstoire du Moyen Age" da "Histoire Générale" sob a direçáo de Gustave Glotz. Paris. Presses Universitalres de France. 1933. pág. 57.

(18) . - Pirenne, op. cit., págs. 57-58. 
cujas pessoas pertenciam ao senhor. Entre êles é que se recrutavam os trabalhadores da reserva senhorial, os pastores, os obreiros dos dois sexos ocupados nos trabalhos do "gineceu", têrmo que designava as oficinas onde se teciam o linho e a lã produzidas na propriedade. Também era entre êles que se recrutavam os ferreiros, os carreiros, vinhateiros, cervejeiros, etc. Essa servidão era menos pronunciada entre os que arroteavam os mansi e que por isso eram chamados de casati. Havia inúmeras nuances, mas pouco a pouco todos acabaram por adquirir a terra que trabalhavam por hereditariedade, prática que aliás estava fortemente estabelecida. Entre êles existiam antigos homens livres, ou seus descendentes, que tinham perdido a liberdade pela obrigação das corvéias e prestações de impostos oriundos do cultivo do mansus. Nos domínios eclesiásticos havia uma classe especial chamada cerocensuales por serem descendentes, na sua maioria, de viúvas de condição livre que se tinham colocado sob a proteção monástica, em troca da liberdade das terras de que eram possuidoras, com a condição de conservar o uso-fruto das mesmas, pagando, entretanto, uma pequena prestação que consistia em certa porção de cêra para as festas religiosas. Existia ainda os cotarii ou bordarii, que possuiam um pequeno pedaço de terra, e se empregavam como trabalhadores agrícolas em propriedades senhoriais ou do mansuário (19).

Os laços de dependência da população que vivia numa grande propriedade eram ainda aumentados pelo fato de tôda ela estar sob a jurisdição do senhor, representando pelo seu villicus nas côrtes que se reuniam para examinar um delito contra os costumes estabelecidos. Para determinados crimes era competente a justiça real. Também na residência do senhor (dominus) sempre havia uma capela ou igreja. Nestas condições, cada villa representava um todo judiciário e uma unidade eclesiástica. Cada domínio era também uma unidade social, pois todos eram homens do senhor e o poderio dêste se media pelo número de dependentes que possuísse. Assim, êle assumia também um aspecto patriarcal em que o senior tinha por obrigação defender os seus dependentes e os abrigar em caso de necessidade na sua fortaleza $(20)$.

Esses domínios tinham uma economia fechada, isto é, eram verdadeiras autarquias. Tôdas as necessidades do senhor e dos arrendatários eram cobertas pela produção da propriedade. Esta não produzia nada em excesso, pois não tinha a quem vender, ou se o fazia era esporàdicamente. Acumulava-se apenas uma pequena reserva de grãos para o caso de más colheitas e para se prevenir contra a fome. Certas abadias chegaram ao cúmulo de possuir propriedades em territórios onde a vinha medrava, apenas para a obtenção do vinho necessário à

(19) . - Ibtdem, págs. 58-59.

(20). - Ibldem pág. 59 . 
missa (21). Plantava-se e produzia-se o que se tinha necessidade, mesmo que as condições não fôssem boas e isso explica também porque tôdas as villae tinham um sem número de especialistas. Para se ter uma idéia da complexidade econômica dum domínio basta examinarmos a famosa Capitulare de Villis de Carlos Magno (22).

Os mansi geralmente tinham uma forma alongada, pois assim haveria facilidades para que a charrua pudesse arroteá-los sem dar muitas voltas. Isso é ainda notado em diversas' regiões da Europa que guardaram êsse costume, sendo visível principalmente nas fotografias aéreas. Fazia-se nesses campos a rotação trienal - cousa que sòmente agora começamos a praticar na nossa agricultura - e todos animais e utensílios eram usados em comum.

Nesses domínios existiam também os direitos senhoriais, que iam desde a licença para o servo casar-se - mediante uma taxa, é claro - até o de receber parte ou a totalidade de sua herança, sem falar das famosas banalidades que mostram como era pesada a mão do senhor.

As corvéias, ou as prestações in natura, variavam de acôrdo com a qualidade das terras e com o grau de liberdade usufruida pelos servos. Distingüia-se para êsse efeito diversos tipos de mansi: os ingenuiles, os serviles, os lidiles, conforme o seu ocupante: um servo de corpo, um lite (semi-livre) ou um homem livre.

Por sua vez o senhor tinha de pagar ao seu suzerano diversas taxas que variavam também de acôrdo com sua fôrça, não se incluindo nisso o pagamento do dízimo devido à Igreja .

No século XIII o quadro que procuramos traçar da villa medieval foi extraordinàriamente modificado, pois não só a população aumentou, como novas áreas foram ganhas à floresta e pântanos, ampliando dessa forma as zonas arroteáveis. Também novas técnicas agrícolas foram empregadas e incorporadas à rotina. Mas o essencial foi a mudança operada com o restabelecimento do comércio, que modificou completamente o quadro das grandes propriedades, pois agora com o aparecimento de grandes mercados consumidores, o senhor pôde fazer o seu domínio render o máximo possível, tirando do seu solo os produtos que melhor podiam ser cultivados. A situação do trabalhador melhorou sensivelmente e a servidão da gleba não se tornou mais necessária e pouco a pouco foi desaparecendo.

\section{III. - OS ENGENHOS E FAZENDAS DO BRASIL COLONIAL.}

Com a descoberta e apossamento do Brasil, Portugal viu-se a braços com um grande problema: a defesa dum vasto território com

(21). - Ferdinand Lot, op. cit., pág. 598.

(22). - Ibidem, pag. 559. 
a pequena população que possuia. Como valorizar tão grande país, levando-se em conta a concorrência da África e da India? A solução veio com as capitanias hereditárias e, em seguida, com o Govêrno Geral. Os donatários e governadores concederam a particulares e, posteriormente, a ordens monásticas, grandes tratos de terra que se - chamaram sesmarias. Aliás, êsse sistema de donatárias já fôra aplicado pelos portuguêses na Madeira e depois nos arquipélagos atlânticos. Os mesmo acontecia com as sesmarias, instituto existente no Portugal medieval.

Os donatários e sesmeiros procuravam povoar as suas concessões de terras da melhor maneira possível, fazendo vir colonos de Portugal e preando índios para os trabalhos mais rudes. Não vamos entrar aqui na história dos primórdios do Brasil e nem na história da escravidão vermelha ou negra, consequiência das tentativas de exploração das possibilidades então oferecidas pela colônia.

Em São Vicente, e principalmente no Recôncavo Baiano e na Zona da Mata no Nordeste, a cultura canavieira desenvolveu-se sobremaneira com o auxílio do braço escravo e paulatinamente se foram formando grandes propriedades que se desenvolveram em função das necessidades da Metrópole - principalmente a produção do açúcar que Portugal e Flandres distribuiam pela Europa. Dentro dêsse latifúndio, como seu ponto de concentração, foi edificada a Tasa Grande, tão bem descrita por Gilberto Freyre e que inicialmente teve o aspecto duma verdadeira fortaleza, tal a espessura dos seus muros de taipa, com poucas janelas e geralmente com grandes páteos internos. Com o decorrer do tempo e por não mais ser necessário, perdeu êsse aspecto rebarbativo. Ao lado da Casa Grande apareceu a Senzala e a Capela. Como no período medieval, a Casa Grande simboliza o poder senhorial, a Capela o poder espiritual e a Senzala o servo da gleba. Indios e negros armados desempenham o papel dos servos armados para defesa do domínio. Com o passar dos anos os agregados foram aparecendo, vivendo e usufruindo duma porção do solo, recebendo proteção, mas ao mesmo tempo que com o seu arcabuz aumentavam o poderio do senhor do engenho.

Apesar do grosso da produção do açúcar ser destinado à exportação, o latifúndio procurava produzir tudo o que lhe fôsse possível, chegando alguns mesmo a importar apenas o sal e a pólvora. Com a mineração deu-se o mesmo fenômeno. Devido à longa distância dos centros abastecedores, procurou-se produzir in loco o possível em bens de consumo.

As pequenas propriedades se mantiveram com grandes dificuldades e muitas sucumbiram. As comunidades agrícolas de índios reduções - desapareceram ante a investida dos colonos que, na sua violência acabaram por expulsar os jesuítas. Pouco a pouco o que 
restou dessas aglomerações foi sendo absorvido pela onda da ocupação partida do litoral rumo ao sertão.

Assim, grosso modo, o latifúndio constituiu-se na unidade econômica nos primeiros tempos da colônia, baseado principalmente na agricultura e no pastoreio, complementado por pequenas indústrias subsidiárias e autárquicas.

O fazendeiro, através dos seus capatazes, feitores e administradores explorava diretamente parte dos seus vastos domínios. Ās vêzes arrendava uma pequena parcela, mas na maioria dos casos deixava improdutiva grandes áreas sob a forma de matas, capoeiras e mesmo pastagens.

Tal fenômeno aparece também na América Espanhola (23). A hacienda pode ser comparada com o nosso engenho, com as nossas fazendas e estâncias. Em tôrno delas é que se concentrou a vida rural - sem dúvida a que maior papel desempenhou no período colonial - e é nela, que o elemento nativista procurou se apoiar contra os reinóis que dominavam nas cidades. No fim do século XVII, a hacienda, na América Espanhola, como os nossos engenhos e fazendas, atestam a importância e a extensão da vida rural em tal grau que pode ser comparada, com certa semelhança, tanto com a villa romana durante o Baixo-Império, como com grande latifúndio de certas áreas da Europa Ocidental .

\section{CONCLUSÕES.}

Que podemos concluir de tudo isso? Poder-se-ia admitir que a villa romana surgiu como conseqüência do emperramento das correntes comerciais. Assim, paulatinamente, a economia do Baixo-Império foi se transformando num organismo fossilizado, que procurava bastar-se a si próprio, constituindo uma verdadeira autarquia. O mesmo fenômeno se observa na Alta Idade Média, quando a moeda deixou de ter curso e só teve importância e valor a terra. A tese de Henri Pirenne, sôbre ó fechamento do Mediterrâneo (24), é bem clara nesse sentido. Com o renascimento comercial, urbano e cultural a situação modificou-se bastante, pois basta ver o aparecimento de grande número de cidades novas e o aumento substancial da área arroteável.

$\mathrm{Na}$ América, e em especial no Brasil, a economia dos primeiros séculos, pela própria falta de comunicaçōes, foi embrionária e por isso revestiu-se das mesmas características da economia do Bai-

(23). - Vide J. Vicens Vives (sob a direçấ de), História Social y económica de España y America. Tomo III. Império, Aristocracia. Absolutismo. Editorlal Teide. Barcelona, pág. 508.

(24). - Henri Pirenne, Mahomet et Charlemagne. Fellx Alcan. Paris. 1937. 3a. ediçăo, págs. 143-152. 
xo-Império e da Alta Idade Média. Os senhores de engenhos e os fazendeiros, ou ainda os pequenos proprietários, procuraram produzir ao máximo as mercadorias que podiam ser exportadas, principalmente o açúcar, fato perfeitamente compreensivel se levarmos em conta a política monopolista dos países ibéricos. Devido à falta de transporte e de indústrias locais de importância, tudo foi produzido in loco, ou pelo menos em grande parte. Mesmo aí a interferência da Corôa foi drástica, pois a ela não interessava que as colônias tivessem indústrias ou produzissem gêneros agrícolas em condições de competir com os da Metrópole. Daí a política do monopólio do sal, e de tantas outras coisas que conservam ainda no Brasil o rótulo "... do Reino". Isso estimulou a economia fechada, principalmente nos latifúndios mais afastados da costa, do sul ao norte do país.

Ainda nesse estudo comparativo não devemos deixar de mencionar o escravo da villa da época imperial, o servo da gleba medieval e o nosso escravo índio ou negro. Todos trabalharam para um determinado senhor: senador romano, barão medieval ou fazendeiro brasileiro. Com isso não queremos dizer que houvesse feudalismo no Brasil. Longe disso, pois nem sequer existiu integralmente essa instituição na Península Ibérica - e a fortiori em Portugal — pois a condição principal, a dispersão do poder, não existiu na Metrópole e nem na colônia.

O latifúndio - hoje tão combatido - foi uma forma, talvez a única possível devido às circunstâncias, de exploração da terra. Não justificamos o latifúndio, mas compreendemos a razão dêle haver existido, pois tanto no Baixo-Império, como na Alta Idade Média, assim como no período colonial brasileiro, sempre existiu uma economia subdesenvolvida. Com o fortalecimento econômico, o latifúndio foi desaparecendo, sendo substituído por culturas em que o solo pôde ser melhor aproveitado.

Concluindo as nossas consideraçốes, pensamos que para o Brasil vale mais um latifúndio em franca produção, de um só dono ou de muitos, do que um minifúndio improdutivo. Somos uma nação que luta para sair duma economia subdesenvolvida, em grande expansão demográfica, cuja curva de crescimento, infelizmente, não é acompanhada por outra da área arroteada e da produção. 